\title{
Anti-SARS-CoV-2 activity of Andrographis paniculata extract and its major component Andrographolide in human lung epithelial cells and cytotoxicity evaluation in major organ cell representatives
}

Khanit Sa-ngiamsuntorn, ${ }^{1, \#, ~ A m p a ~ S u k s a t u ~}{ }^{2, \#}$, Yongyut Pewkliang 3 , Piyanoot Thongsri ${ }^{3}$, Phongthon Kanjanasirirat ${ }^{4}$, Suwimon Manopwisedjaroen ${ }^{2}$, Sitthivut Charoensutthivarakul ${ }^{4,5,6}$, Patompon Wongtrakoongate ${ }^{6,7}$, Supaporn Pitiporn ${ }^{8}$, Phisit Khemawoot ${ }^{9}$, Somchai Chutipongtanate ${ }^{9,10}$, Suparerk Borwornpinyo ${ }^{4,11,{ }^{*}}$, Arunee Thitithanyanont ${ }^{2,}$ Suradej Hongeng ${ }^{4,10}$

${ }^{1}$ Department of Biochemistry, Faculty of Pharmacy, Mahidol University, Bangkok 10400, Thailand

${ }^{2}$ Department of Microbiology, Faculty of Science, Mahidol University, Bangkok 10400 Thailand

3 Section for Translational Medicine, Faculty of Medicine Ramathibodi Hospital, Mahidol University, Bangkok 10400, Thailand

${ }^{4}$ Excellent Center for Drug Discovery (ECDD), Faculty of Science, Mahidol University, Bangkok, 10400, Thailand

${ }^{5}$ School of Bioinnovation and Bio-Based Product Intelligence, Faculty of Science, Mahidol University, Bangkok 10400, Thailand

${ }^{6}$ Center for Neuroscience, Faculty of Science, Mahidol University, Bangkok 10400, Thailand

7 Department of Biochemistry, Faculty of Science, Mahidol University, Bangkok 10400,

Thailand

${ }^{8}$ ChaoPhya Abhaibhubejhr Hospital, Prachin Buri 25000, Thailand

${ }^{9}$ Chakri Naruebodindra Medical Institute, Faculty of Medicine Ramathibodi Hospital, Mahidol University, Samutprakarn 10540 Thailand

${ }^{10}$ Department of Pediatrics, Faculty of Medicine Ramathibodi Hospital, Mahidol University, Bangkok 10400, Thailand

11 Department of Biotechnology, Faculty of Science, Mahidol University, Bangkok 10400, Thailand

\#These authors contributed equally to this work

* Shared co-corresponding authors:

\section{Corresponding authors:}

Suparerk Borwornpinyo, Ph.D.

Excellence Center for Drug Discovery (ECDD), Faculty of Science, Mahidol University, Bangkok 10400 Thailand.

Tel: +66-2-201-5308

Email: bsuparerk@gmail.com

Arunee Thitithanyanont, M.D.

Department of Microbiology, Faculty of Science, Mahidol University, Bangkok 10400 Thailand. Tel: +66-2-201-5528

Email: arunee.thi@mahidol.edu 


\begin{abstract}
The coronavirus disease 2019 (COVID-19) caused by a novel coronavirus (SARS-CoV-2) has become a major health problem affecting more than fifty million cases with over one million deaths globally. The effective antivirals are still lacking. Here, we optimized a high-content imaging platform and the plaque assay for viral output study using the legitimate model of human lung epithelial cells, Calu-3, to determine anti-SARS-CoV-2 activity of Andrographis paniculata extract and its major component andrographolide. SARS-CoV-2 at 25TCID 50 was able to reach the maximal infectivity of $95 \%$ in Calu-3 cells. Post-infection treatment of A. paniculata and andrographolide in SARS-CoV-2 infected Calu-3 cells significantly inhibited the production of infectious virions with the $\mathrm{IC}_{50}$ of $0.036 \mu \mathrm{g} / \mathrm{mL}$ and $0.034 \mu \mathrm{M}$, respectively, as determined by plaque assay. The cytotoxicity profile developed over the cell line representatives of major organs, including liver (HepG2 and imHC), kidney (HK-2), intestine (Caco-2), lung (Calu-3) and brain (SH-SY5Y), showed the $\mathrm{CC}_{50}$ of $>100 \mu \mathrm{g} / \mathrm{mL}$ for $A$. paniculata extract and $13.2-81.5 \mu \mathrm{M}$ for andrographolide, respectively, corresponding to the selectivity index over 380 . In conclusion, this study provided experimental evidence in favor of $A$. paniculata and andrographolide for further development as a monotherapy or in combination with other effective drugs against SARS-CoV2 infection.
\end{abstract}

Keywords: SARS-CoV-2, COVID-19, anti-COVID-19, antiviral, Andrographis paniculata, andrographolide, cytotoxicity, high-content screening 


\section{INTRODUCTION}

The outbreak of Coronavirus Disease 2019 (COVID-19) is an emergent global health crisis that requires urgent solutions. Since severe acute respiratory syndrome coronavirus 2 (SARS-CoV2) has been emerged in Wuhan, Hubei, China at the end of $2019,{ }^{1}$ the total confirmed cases are approaching seventy millions with more than one million deaths globally at the end of December 2020. SARS-CoV-2 is a positive sense, single-stranded, enveloped RNA virus belonging to Coronaviridae family, and categorized as a new member of Betacoronavirus genus together with severe acute respiratory syndrome coronavirus (SARS-CoV) in 2003 and middle east respiratory syndrome coronavirus (MERS-CoV) in 2012..$^{2-4}$ The host range of SARS-CoV-2 is very broad partly due to the relative conservation of the cellular receptor, angiotensin-converting enzyme 2 (ACE2), among mammals. This phenomenon could explain the interspecies transmission of the virus from animals to cause disease in humans. ${ }^{5}$ Even though the majority of infection was asymptomatic, clinical manifestations of COVID-19 varies widely, ranging from low-grade fever to severe pneumonia and eventually death. The outcome of the infection depended largely on host factors, e.g., age, previous health problems, and immunological status. ${ }^{6-8}$ Among critical manifestations, acute respiratory distress syndrome, cytokine storm, and multi-organ failure are the leading causes of death in COVID-19. ${ }^{9,10}$

Lacking the effective antivirals against SARS-CoV-2 is undoubtedly one of the main reasons of poor clinical outcomes in severe COVID-19 patients. Drug discovery and repurposing strategies are pursuing to identify potential therapeutic agents. ${ }^{11-13}$ A beneficial instance of this effort was repositioning of remdesivir (that originally developed for Ebola virus infection) for COVID-19 treatment. ${ }^{14,15}$ Unfortunately, subsequent well-conducted clinical trials revealed that remdesivir had marginally clinical efficacy, ${ }^{15}, 16$ while the cost-effectiveness and accessibility are still a huge concern. ${ }^{17}$ Therefore, further efforts should be made to identify new compounds with the potent anti-SAR-CoV-2 activity. Among all promising candidates, natural products are recognized as the major source for new drug discovery over decades. ${ }^{18}$ Ethnobotanical evidence suggests plant-derived natural compounds are worth investigating to identify potent antivirals against coronaviruses, ${ }^{19}$ while computational approaches have been applied for phytochemicals in order to define their target-specific antiviral potential against SARS-CoV-2. ${ }^{20}$

One of prominent medicinal plants with various pharmacological activities is Andrographis paniculate, known as "King of bitters", which belongs to Acanthaceae family. ${ }^{21} A$. paniculate is currently used in the traditional medicine to treat common cold, diarrhea, fever due to several infectious causes, and as a health tonic. ${ }^{22}$ A major bioactive component of $A$. paniculata is andrographolide, ${ }^{23}$ a diterpene lactone in the isoprenoid family, which is known for its broadspectrum anti-viral properties. ${ }^{24}$ Andrographolide has recently predicted in silico to have a potent anti-SARS-CoV-2 activity through specific targeting the host ACE2 receptor and the viral factors, i.e., RNA-dependent RNA polymerase, main protease, 3-CL protease, PL protease, and spike protein. ${ }^{25-28}$ Recently, Shi TH, et al., applied an enzyme-based assay to demonstrate an inhibitory effect of andrographolide against SARS-CoV-2 main protease $\left(\mathrm{M}^{\text {pro }}\right){ }^{29}$ Furthermore, our group has utilized a phenotypic cell-based immunofluorescent assay (IFA) to reveal the anti-SARS-CoV2 effect of $A$. paniculata extract and andrographolide in the African green monkey kidney cells (Vero E6). ${ }^{30}$ Notably that the anti-SARS-CoV-2 activity of $A$. paniculata extract and andrographolide has never been elucidated in the infected human lung epithelial cells.

This study aimed to evaluate the anti-SARS-CoV-2 activity of $A$. paniculata extract and its major component andrographolide by using a legitimate model of infected human lung epithelial cell, Calu-3. ${ }^{31}$ Cytotoxic profiles of $A$. paniculata extract and andrographolide over five 
major human organs, including lung, brain, liver, kidney, and intestine were achieved by a panel of cell line representatives. The results demonstrated that $A$. paniculata extract and andrographolide have a potent anti-SARS-CoV-2 activity with a high safety margin for major organs in cell culture models.

\section{MATERIALS AND METHODS}

\section{Cell culture}

African green monkey (Cercopithecus aethiops) kidney epithelial cells (Vero cells) (ATCC ${ }^{\circledR}$ CCL-81), Vero cell derivative (Vero E6 cells) (ATCC ${ }^{\circledR}$ CRL-1586), human liver cancer cell line (HepG2) $\left(\mathrm{ATCC}^{\circledR} \mathrm{HB}-8065\right)$, human colon cancer cell line (Caco-2) $\left(\mathrm{ATCC}^{\circledR} \mathrm{HTB}-37\right)$, human airway epithelial cell line (Calu-3) $\left(\mathrm{ATCC}^{\circledR} \mathrm{HTB}-55^{)}\right.$, human neuroblastoma cell line (SHSY5Y) (ATCC ${ }^{\circledR}$ CRL-2266) and human normal kidney (HK-2) (ATCC ${ }^{\circledR}$ CRL-2190) were obtained from American Type Culture Collection (ATCC, Manassas, VA, USA). An Immortalized Hepatocyte-Like Cell Line (imHC) was established in-house as previously described $^{56}$ and its hepatic phenotypes were characterized previously. ${ }^{57,58}$ Vero cells were cultured in Minimum Essential Medium (MEM) (Gibco, Detroit, MI, USA). Vero E6 cells and Caco-2 were cultured in Dulbecco's Modified Eagle's Medium (DMEM) (Gibco, Detroit, MI, USA). HepG2, imHC, Calu-3, and SH-SY5Y cells were cultured in Dulbecco's Modified Eagle Medium:Nutrient Mixture F-12 (DMEM/F-12) (Gibco, Detroit, MI, USA). HK-2 cells were cultured in Dulbecco's Low Glucose Modified Eagles Medium (DMEM low glucose) (HyClone, Logan, UT, USA). The culture media was supplemented with $10 \%$ fetal bovine serum (FBS) (Thermo Scientific Fisher, Waltham, MA, USA) and $100 \mu \mathrm{g} / \mathrm{mL}$ penicillin/streptomycin (Invitrogen, Carlsbad, CA, USA) and 1\% GlutaMAX ${ }^{\mathrm{TM}}$ (Gibco, Detroit, MI, USA). Cells were incubated at $37^{\circ} \mathrm{C}$ in a humidified incubator with $5 \% \mathrm{CO}_{2}$.

\section{Preparation of SARS-CoV-2 virus}

SARS-CoV-2 virus was isolated from nasopharyngeal swabs of a confirmed COVID-19 patient in Thailand (SARS-CoV-2/01/human/Jan2020/Thailand). The virus was propagated in Vero E6 cells as previous described ${ }^{30}$ and stored at $-80^{\circ} \mathrm{C}$. Viral titration as TCID 50 titer $/ \mathrm{mL}$ was performed in the 96-well plate. In brief, the virus stock was titrated in quadruplicate in 96-well plates on Vero E6 cells in serial dilution to obtain 50\% tissue culture infectious dose (TCID 50 ) using the Reed Muench method. ${ }^{59}$ All the experiments with live SARS-CoV-2 viruses were performed at a certified biosafety level 3 facility at Department of Microbiology, Faculty of Science, Mahidol University.

\section{Preparation of Andrographis paniculata extract and andrographolide}

Plant material in this study was common herbs in Thailand, and it was listed in Thai Herbal Pharmacopoeia 2019 (https://bdn.go.th/th/sDetail/10/34/). The plant was identified, authenticated by Chao Phya Abhaibhubejhr Hospital, Prachin Buri, Thailand, and deposited at the herbarium unit. The powder of Andrographis paniculata was weighed and soaked in $95 \%$ ethanol in a ratio of 1:4. After 24 hours, liquid fraction was separated using a thin straining cloth then filtered through filter paper by vacuum pump. The extract was obtained was concentrated using rotary evaporator at temperature $45^{\circ} \mathrm{C}$ and then concentrated in water bath at $70^{\circ} \mathrm{C}$ until it turned concentrated solution. The crude extract was stored at $4^{\circ} \mathrm{C}$ and protected from light until use. ${ }^{60}$ The andrographolide concentration in the crude extract was measured by HPLC method in 
following Thai Herbal Pharmacopoeia 2019 protocol. The andrographolide content in crude extract was $7.9 \%(\mathrm{w} / \mathrm{w}) .{ }^{61}$ The analytical standard andrographolide was used as a reference (Sigma, St. Louis, MO, USA).

\section{In vitro antiviral assay}

Calu-3 cells were seeded at $1 \times 10^{4}$ cell per well in a 96-black well plate (Corning, NY, USA) and incubated for $24 \mathrm{~h}$ at $37^{\circ} \mathrm{C}$ in $5 \% \mathrm{CO}_{2}$ atmosphere. Then, culture media was discarded and washed once with phosphate-buffered saline (PBS). Cells were infected with SARS-CoV-2 at $25 \mathrm{TCID}_{50}$ for $2 \mathrm{~h}$ at $37^{\circ} \mathrm{C}$. After viral adsorption, the cells were washed twice with PBS to remove the excessive inoculum, and the fresh culture medium (DMEM/F12 supplemented with $10 \% \mathrm{FBS}$, $100 \mu \mathrm{g} / \mathrm{ml}$ Penicillin/Streptomycin) was added. Each concentration of drugs, crude extract, or active compound was inoculated into the culture medium. Infected cells were then maintained at $37^{\circ} \mathrm{C}$ in $5 \% \mathrm{CO}_{2}$ incubator for $48 \mathrm{~h}$. Positive convalescent serum (heat-inactivated at $56^{\circ} \mathrm{C}$ for 30 min) of a COVID-19 patient and anti-human IgG (Santa Cruz Biotechnology, Dallas, TX, USA) were used for a viral inhibition as positive control and negative control, respectively. The experiment was performed in triplicate.

\section{High-content imaging for SARS-CoV-2 nucleoprotein detection}

The cells in the 96-well plate were fixed and permeabilized with $50 \%(\mathrm{v} / \mathrm{v})$ acetone in methanol on ice for $20 \mathrm{~min}$. The fixed cells were washed once with phosphate-buffered saline with $0.5 \%$ Tween detergent (PBST) and blocked with $2 \%(\mathrm{w} / \mathrm{v}) \mathrm{BSA}$ in PBST for $1 \mathrm{~h}$ at room temperature. Next, the cells were incubated with 1:500 dilution ratio of primary antibody specific for SARS-CoV nucleoprotein ${ }^{56}$ (Rabbit $\mathrm{mAb}$ ) (Sino Biological Inc. China), which cross-reacting with the NP protein of SARS-CoV-2 as well, for $1 \mathrm{~h}$ at $37^{\circ} \mathrm{C}$. After incubation, cells were washed with PBST three times. Then, the Goat anti-Rabbit IgG Alexa Fluor 488 (Thermo Scientific Fisher, Waltham, MA, USA) was used as the secondary antibody at 1:500 dilution. Hoechst dye (Thermo Scientific Fisher, Waltham, MA, USA) was applied for nuclei staining. The fluorescent signal was detected and analyzed by the Operetta high-content imaging system (PerkinElmer, Waltham, MA, USA) as previously described. ${ }^{30}$ Percentage of the infected cells in each well was automatically obtained from 13 fields per well using Harmony software (PerkinElmer, Waltham, MA, USA). Data was normalized to the infected control, and $\mathrm{IC}_{50}$ value was calculated by GraphPad Prism 7.

\section{Plaque assay}

The viral output in culture supernatants obtained from SARS-CoV-2-infected Calu-3 cells were determined by plaque assay by using Vero cell monolayer. In brief, Vero cells were seeded into 6-well plate 24-h prior to infection. A serial dilution of the virus-containing supernatants was prepared for inoculation into Vero cell monolayer. The cells were incubated for viral adsorption for $1 \mathrm{hr}$ at $37^{\circ} \mathrm{C}$ incubator and then overlaid with $3 \mathrm{~mL} /$ well of MEM medium supplemented with $5 \% \mathrm{FBS}$ and $1 \%$ agarose. The culture was incubated at $37^{\circ} \mathrm{C}$ in $5 \% \mathrm{CO}_{2}$ for three days. Thereafter, plaque phenotypes were visualized by staining with $0.33 \%$ Neutral Red solution (Sigma-Aldrich, St. Louis, MO, USA) for $5 \mathrm{hrs}$. Plaque numbers were counted as plaque-forming units per milliliter (PFUs/mL) and reported as the percentage of plaque reduction in comparison to supernatant obtained from the infected Calu-3 without any treatment.

\section{Cell cytotoxicity assay}


All human cell lines were plated in 96-well plates at $5 \times 10^{4}$ cells/well and treated with various concentrations of Andrographis paniculata extract (0-100 $\mu \mathrm{g} / \mathrm{mL})$ and Andrographolide (0-100 $\mu \mathrm{M})$ for $48 \mathrm{~h}$. Cell viability was examined by an MTT colorimetric assay. In brief, the medium was replaced with MTT [3-(4,5-dimethylthiazol-2-yl)-2,5-diphenyltetrazolium bromide] (SigmaAldrich, St. Louis, MO, USA) final concentration at $0.5 \mathrm{mg} / \mathrm{mL}$ and incubated for $4 \mathrm{~h}$ at $37^{\circ} \mathrm{C}$ in a humidified incubator with $5 \% \mathrm{CO}_{2}$. The rest of MTT solution was removed, and formazan crystals were then dissolved with DMSO (Merck, Schuchardt, Darmstadt, Germany). Absorbance was measured at a wavelength of $570 \mathrm{~nm}$ by EnVision Multilabel Reader (PerkinElmer, Waltham, MA, USA). Data was normalized to the solvent control, and then $\mathrm{CC}_{50}$ values were calculated using GraphPad Prism 7.

\section{RESULTS AND DISCUSSION}

\section{Optimization of human lung epithelial cells (Calu-3)-based anti-SARS-CoV-2 assay}

Urgent demands of the effective anti-SARS-CoV-2 agents draw many attentions of scientific communities to explore for new antiviral candidates. In this study, we aimed to document the anti-SARS-CoV-2 activity of $A$. paniculata extract and andrographolide (Figure 1A) for further drug development against COVID-19. Therefore, a robust anti-SARS-CoV-2 screening platform established on the legitimate model is required to facilitate this process. For serving this proposes, we optimized our antiviral assay (which previously established upon Vero E6 cells) ${ }^{30}$ to use Calu-3 human lung epithelial cells as the legitimate host cell for SARS-CoV-2 infection, ${ }^{31}$ and then validated the assay applicability by hydroxychloroquine and niclosamide (Figure $\mathbf{1 B}$ and 1C, respectively), two FDA-approved drugs with anti-SAR-CoV-2 activities in vitro. ${ }^{31-33}$

A<smiles>C=C1CC[C@]2(CO)[C@@H](CO)[C@@H](O)CC[C@]2(C)[C@H]1C/C=C1\C(=O)OC[C@@H]1O</smiles>

B<smiles>CCN(CCO)CCCC(C)Nc1ccnc2cc(Cl)ccc12</smiles>

Hydroxychloroquine
C<smiles>O=C(Nc1ccc([N+](=O)[O-])cc1Cl)c1cc(Cl)ccc1O</smiles>

Niclosamide

Andrographolide

Figure 1. The chemical structures of candidate compounds for screening as anti-SARS-CoV2 agents. The structure of bioactive compound andrographolide extracted from Andrographis paniculata (A). The structures of classical FDA-approved drugs hydroxychloroquine (B) and niclosamide (C) which can exhibit anti-SARS-CoV-2 activity in vitro.

Calu-3 cells were cultured until reach confluence, and then infected with various concentrations of SARS-CoV-2, ranging from 0.25 TCID $_{50}, 2.5$ TCID $_{50}$, and 25 TCID $_{50}$ for 2 hrs. The cells were washed twice to remove the excessive inoculum, and further incubated in the fresh culture medium for $48 \mathrm{hrs}$ in the absence or presence of the compounds of interest. To demonstrate 
the degree of SARS-CoV-2 infectivity, the infected Calu-3 cells were strained by anti-SARSCoV2 nucleoprotein rabbit monoclonal antibody, following by goat anti-rabbit IgG Alexa Fluor 488 , and counted the percentage of fluorescent positive cells by the high-content imaging platform. The percentage of viral infectivity in Calu-3 cells at 48 hours post-infection achieved approximately $1 \%, 18 \%$ and $95 \%$, upon infection at $0.25 \mathrm{TCID}_{50}, 2.5 \mathrm{TCID}_{50}$, and $25 \mathrm{TCID}_{50}$, respectively (Figure 2A and 2B upper panel). Since SARS-CoV-2 at 25TCID 50 was able to reach maximal infectivity, it was served as the standard infectious dosage throughout all experiments. To establish the positive control, the neutralizing serum derived from COVID-19 patients with negative SARS-CoV-2 RNA was added to the infected Calu-3 cells. The high-content imaging revealed viral suppression in Calu-3 cells with the percentage of SARS-CoV-2 infectivity of $0 \%$, $10 \%, 60 \%$ and $80 \%$ at $1: 100,1: 500,1: 2,500$ and $1: 25,000$ dilutions of the neutralizing serum, respectively (Figure 2A and $\mathbf{2 B}$ lower panel). In this study, anti-human IgG was served as the negative control.

A

C
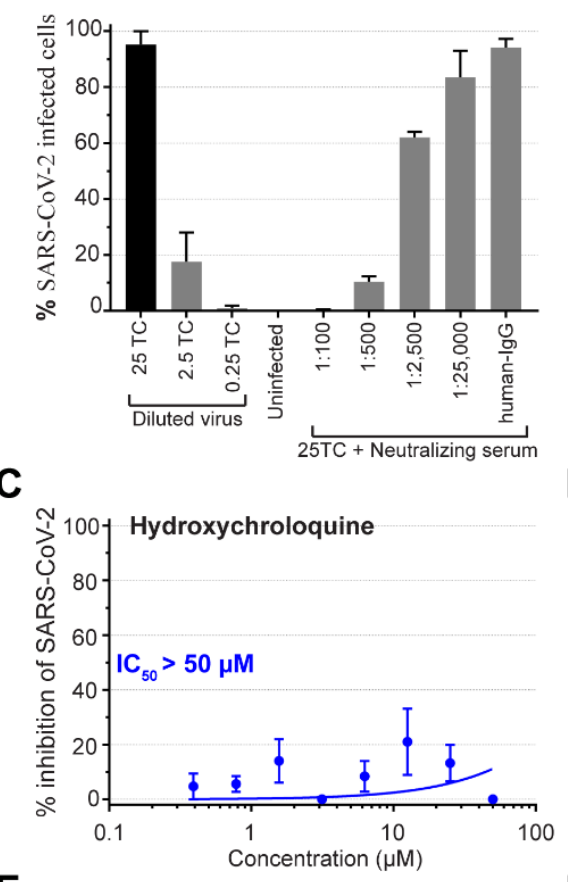

E

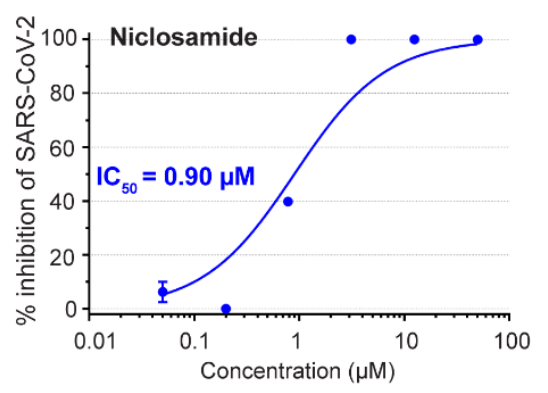

B
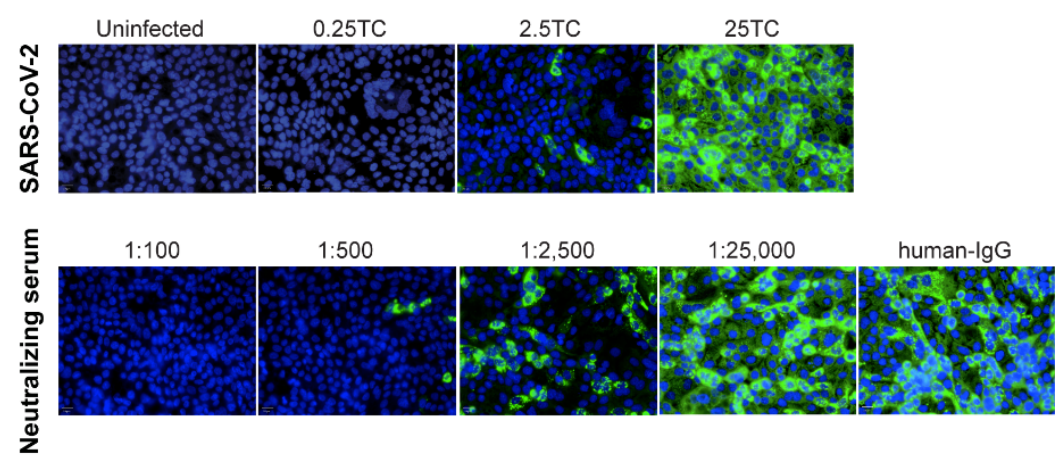

D

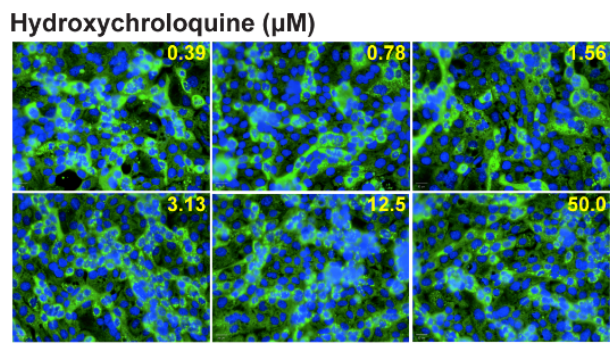

$\mathbf{F}$

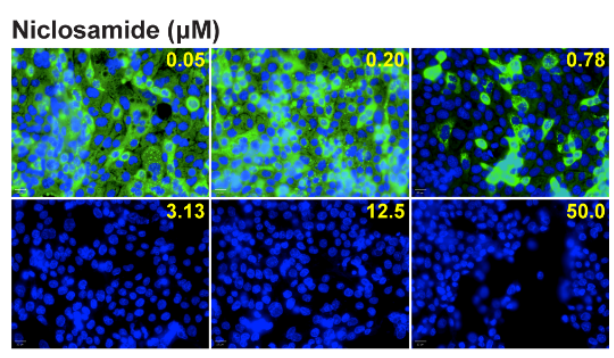

Figure 2. Optimization and validation of anti-SARS-CoV-2 assay using human lung epithelial (Calu-3) cells. (A) The optimal dilutions of SAR-CoV-2 TCID 50 , varying from 0.25 , 2.5 and 25-fold, were evaluated in Calu-3 cells, in which the $25 \mathrm{TCID}_{50}$ showed the maximal 
infectivity and was used throughout this study. FITC-labeled anti- SARS-CoV nucleoprotein mAb was used to detect the degree of SAR-CoV-2 viral replication. The positive control, neutralizing serum, demonstrated the dose-dependent effect, whereas the negative control human IgG had no antiviral activity. (B) Representative fluorescent images show SARS-CoV-2 infectivity at different TCID $_{50}$ (upper row) and anti-SAR-CoV-2 activity of neutralizing serum as compared to human-IgG (lower row). Fluorescent signals: green, anti-SARS-CoV NP mAb; blue, Hoechst. (C) Hydroxychloroquine exhibited no effect against SARS-CoV-2 in Calu-3 with $\mathrm{IC}_{50}>50 \mu \mathrm{M}$. (D) Representative fluorescent images of hydroxychloroquine experiment. (E) Niclosamide represented the dose-dependent anti-SARS-CoV-2 activity in Calu-3 with $\mathrm{IC}_{50}=0.90 \mu \mathrm{M}$. (F) Representative fluorescent images of niclosamide experiment.

As aforementioned, hydroxychloroquine and niclosamide ${ }^{31-33}$ were applied to evaluate the validity of Calu-3-based anti-SARS-CoV-2 assay. Hydroxychloroquine, a classical anti-malarial drug, had no inhibitory effect against SARS-CoV-2 infection in human lung epithelial cells $\left(\mathrm{IC}_{50}>50 \mu \mathrm{M}\right)$ (Figure 2C and 2D), while niclosamide, a classical anti-helminthic drug, inhibited SARS-CoV-2 infection with the $\mathrm{IC}_{50}$ of $0.90 \mu \mathrm{M}$ (Figure $\mathbf{2 E}$ and 2F). Of note, hydroxychloroquine can exhibit antiviral effect in Vero E6 cells ${ }^{30}$ but not Calu-3 human lung epithelial cells. ${ }^{31}$ These results were consistent to previous reports ${ }^{31,32}$ and supported the validity of Calu-3-based anti-SARS-CoV-2 assay used in this study.

\section{Dose-response relationship of $A$. paniculata extract and andrographolide in SARS-CoV-2 infected human lung epithelial cells}

To investigate whether $A$. paniculata extract and its major component andrographolide have potentials for anti-SARS-CoV-2 agents, SARS-CoV-2 infected Calu-3 cells were treated for 48 -h with 4-fold dilutions of $A$. paniculata extract $(0.05-50 \mu \mathrm{g} / \mathrm{mL})$ or andrographolide $(0.05-50$ $\mu \mathrm{M}$ ), respectively. The results demonstrated both $A$. paniculata extract (Figure 3A and 3B) and andrographolide (Figure 3C and 3D) inhibited SARS-CoV-2 replication in the dose-dependent manner. 
A

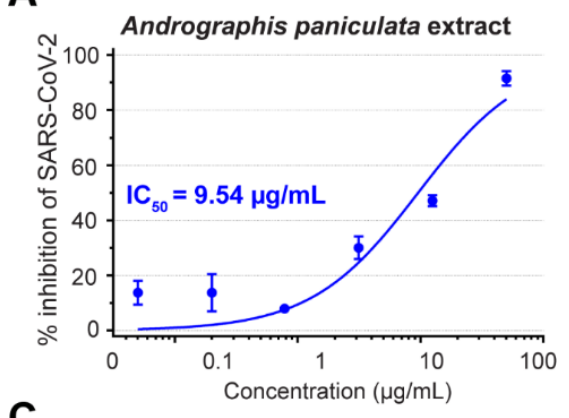

C

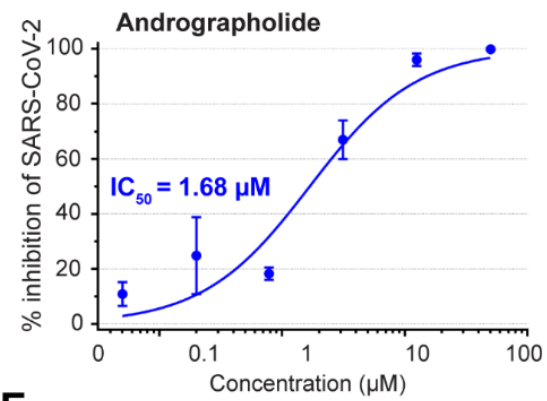

$\mathbf{E}$

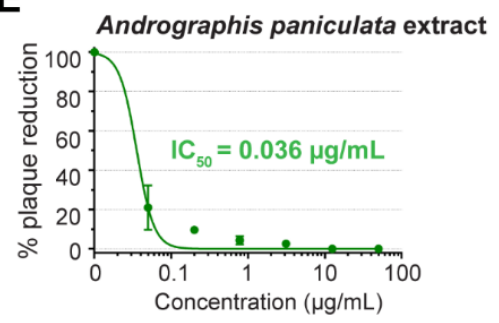

B

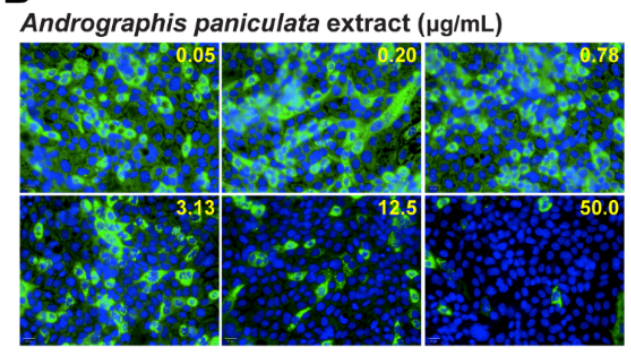

D

Andrographolide $(\mu \mathrm{M})$

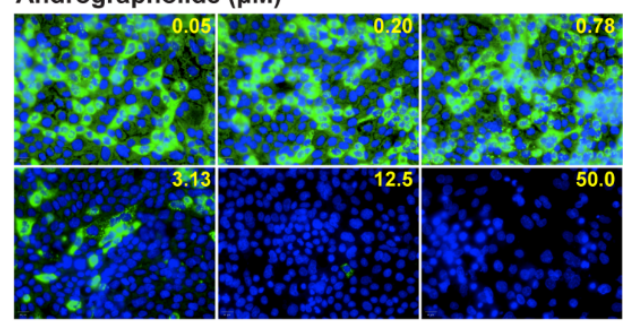

$\mathbf{F}$

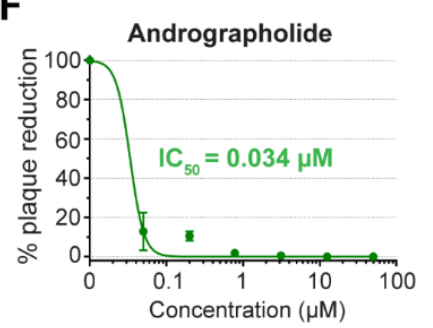

Figure 3. Anti-SARS-CoV-2 activity of Andrographis paniculata extract and andrographolide. SARS-CoV-2 infected Calu-3 (at 25TCID 50 ) was treated with various concentrations of $A$. paniculata extract or andrographolide for $48 \mathrm{~h}$ before harvesting for highcontent imaging analysis. (A) A. Paniculata extract showed the dose-dependent inhibition of SARS-CoV-2 infection. (B) Representative fluorescent images of $A$. paniculate experiment. (C) Andrographolide, the major component of A. Paniculata extract, exhibited potent anti-SARSCoV-2 activity. (D) Representative fluorescent images of andrographolide experiment. Inhibition of infectious virions released from SARS-CoV-2 infected Calu-3 was evaluated by plaque reduction assay after treatment with (E) A. paniculata extract and (F) andrographolide. All experiments were performed in three biological replicates.

To confirm anti-SARS-CoV2 activity of $A$. paniculata extract and andrographolide, analysis of viral output using plaque reduction assay was performed. At 48-h post-infection in the absence or presence of compounds of interest, the culture supernatants were harvested to determine the number of the infectious virion production from SARS-CoV-2 infected Calu-3 cells by plaque assay. From the result, evaluation of viral output was consistent to that of high-content imaging study (Figure 3A-3D), in which $A$. paniculata extract and andrographolide again demonstrated the dose-response relationship (Figure 3E and 3F) with the $\mathrm{IC}_{50}$ of $0.036 \mu \mathrm{g} / \mathrm{mL}$ for A. paniculata and $0.034 \mu \mathrm{M}$ for andrographolide (Figure 3E and $\mathbf{3 F}$ ).

It was interesting that the $\mathrm{IC}_{50}$ values of $A$. paniculata extract and andrographolide varied between the high-content imaging IFA and viral output study using plaque assay. Taking our 
previous study ${ }^{30}$ into account, the $\mathrm{IC}_{50}$ of $A$. paniculata extract and andrographolide by the types of measure and cell host can be summarized in Table 1. The IC50 values of remdesivir ${ }^{30}$ served $^{2}$ as the comparator.

Table 1. The $\mathrm{IC}_{50}$ values of $A$. paniculata extract, andrographolide, and remdesivir evaluated by high-content imaging IFA and plaque assay in Vero E6 and Calu-3.

\begin{tabular}{|l|c|c|c|c|c|c|}
\hline \multirow{3}{*}{ Cell lines } & \multicolumn{2}{|c|}{ A. paniculata extract } & \multicolumn{2}{c|}{ Andrographolide } & \multicolumn{2}{c|}{ Remdesivir $^{\mathrm{a}}$} \\
\cline { 2 - 7 } & $\begin{array}{c}\mathrm{IFA} \\
\left(\mathrm{IC}_{50 ;} \mu \mathrm{g} / \mathrm{mL}\right)\end{array}$ & $\begin{array}{c}\text { Plaque } \\
\left(\mathrm{IC}_{50 ;} \mu \mathrm{g} / \mathrm{mL}\right)\end{array}$ & $\begin{array}{c}\mathrm{IFA} \\
\left(\mathrm{IC}_{50 ;} \mu \mathrm{M}\right)\end{array}$ & $\begin{array}{c}\text { Plaque } \\
\left(\mathrm{IC}_{50 ;} \mu \mathrm{M}\right)\end{array}$ & $\begin{array}{c}\mathrm{IFA} \\
\left(\mathrm{IC}_{50 ;} \mu \mathrm{M}\right)\end{array}$ & $\begin{array}{c}\text { Plaque } \\
\left(\mathrm{IC}_{50 ;} \mu \mathrm{M}\right)\end{array}$ \\
\hline Calu-3 & 9.54 & 0.036 & 1.68 & 0.034 & $0.043^{\mathrm{a}}$ & $0.086^{\mathrm{a}}$ \\
\hline Vero E6 $^{\mathrm{a}}$ & $68.06^{\mathrm{a}}$ & $2.21^{\mathrm{a}}$ & $6.58^{\mathrm{a}}$ & $0.28^{\mathrm{a}}$ & $2.71^{\mathrm{a}}$ & $2.65^{\mathrm{a}}$ \\
\hline
\end{tabular}

${ }^{\text {a }}$, data from our previous study ${ }^{30}$

As shown in Table 1, the consistent pattern has been detected for A. paniculata extract, andrographolide, and remdesivir; i) the $\mathrm{IC}_{50}$ values measured from the assays using Calu-3 were lower than those of Vero E6; ii) the IC50 values measured by plaque assay were lower than those of high-content imaging IFA. The deviation of drug response between two cells of differed species and organs highlighted the importance of using Calu-3 human lung epithelial cells, but not Vero E6 African green monkey kidney cells, as the host cells for in vitro SARS-CoV-2 infection experiments. ${ }^{31}$ The dissimilarity of $\mathrm{IC}_{50}$ between the IFA and the plaque assay could be explained by their different principle of SARS-CoV-2 detection. The IFA requires the specific antibody to detect the SARS-CoV-2 nucleoprotein derived from the complete virions and sub-viral particles within the host cells, while the plaque assay measures the infectivity of complete virions released from the host cells. Accordingly, it was not surprising that the $\mathrm{IC}_{50}$ of the IFA was higher than the plaque assay. Since the $\mathrm{IC}_{50}$ of the plaque assay is the standard measure to interpret antiviral potency of the compound of interest, the $\mathrm{IC}_{50}$ based on the plaque assay of $0.036 \mu \mathrm{g} / \mathrm{mL}$ for $A$. paniculata and $0.034 \mu \mathrm{M}$ for andrographolide were applied for data interpretation.

\section{Cytotoxicity profiles of $\boldsymbol{A}$. paniculata extract and andrographolide}

One of the main concerns in medicinal plant-derived drug development is herb-induced injury of the vital organs, especially the liver. To address this issue, six human cell lines which represent five major organs including liver (HepG2 and imHC), kidney (HK-2), intestine (Caco2), lung (Calu-3) and brain (SH-SY5Y) were applied to evaluate the cytotoxicity profiles of $A$. paniculata extract and andrographolide by MTT assay. The results showed that $A$. paniculata extract had no cytotoxicity to all cell lines examined with the $\mathrm{CC}_{50}$ of $>100 \mu \mathrm{g} / \mathrm{mL}$ (Figure 4A4F). Considering the antiviral effect with the $\mathrm{IC}_{50}$ of $0.034 \mu \mathrm{M}$ andrographolide (Figure 3F), this diterpene lactone showed considerably low-to-no cytotoxic effects on HepG2, imHC, HK-2, Caco2 and Calu-3 with the $\mathrm{CC}_{50}$ of $81.52,44.55,34.11,52.30$ and $58.03 \mu \mathrm{M}$, and the selectivity index (SI) of 2398, 1310, 1003, 1538 and 1707, respectively (Figure 4G-4K). Andrographolide treated SH-SY5Y had the $\mathrm{CC}_{50}$ of $13.19 \mu \mathrm{M}$ and the relatively narrower SI of 388 (Figure 4L). The schematic diagram summarized the $\mathrm{IC}_{50}$ and the CC50 values of $A$. paniculata extract and andrographolide is shown in Figure 5. 


\section{A}
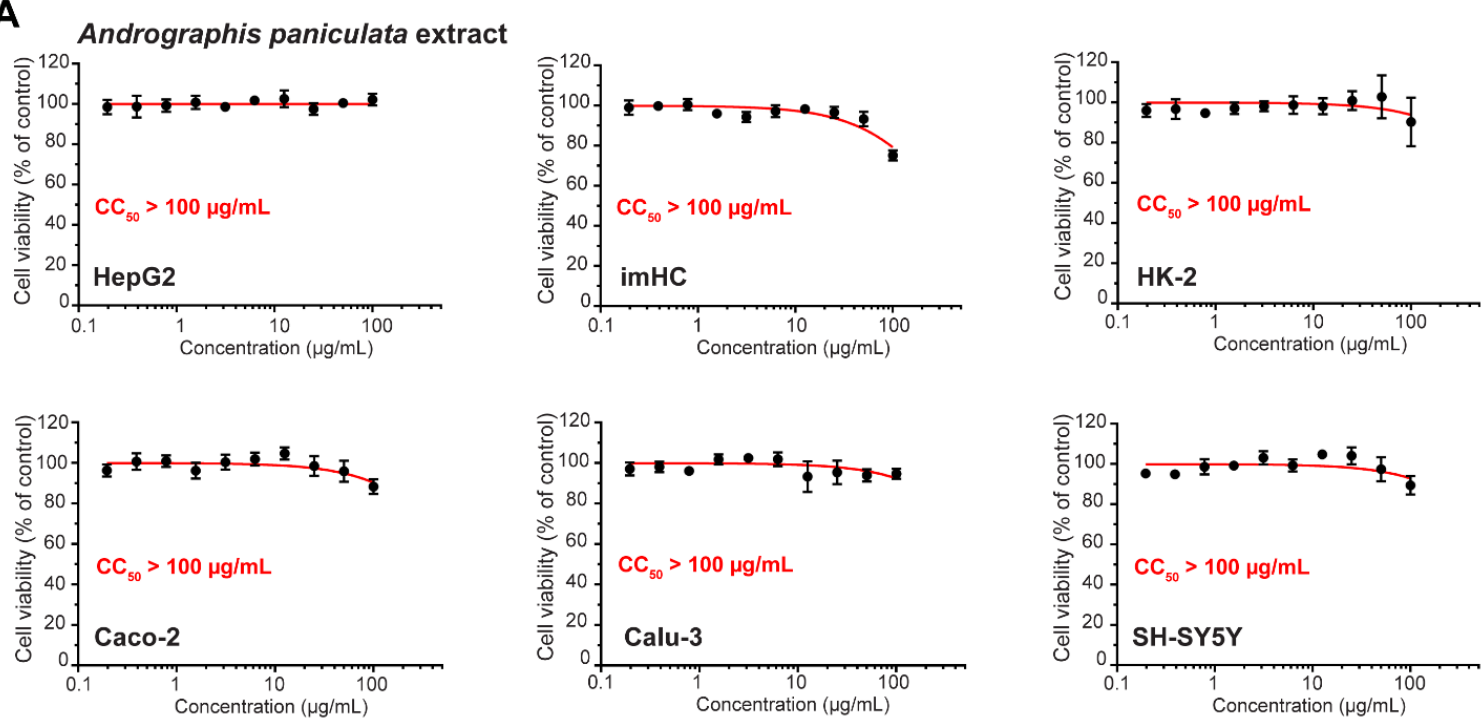

\section{B}
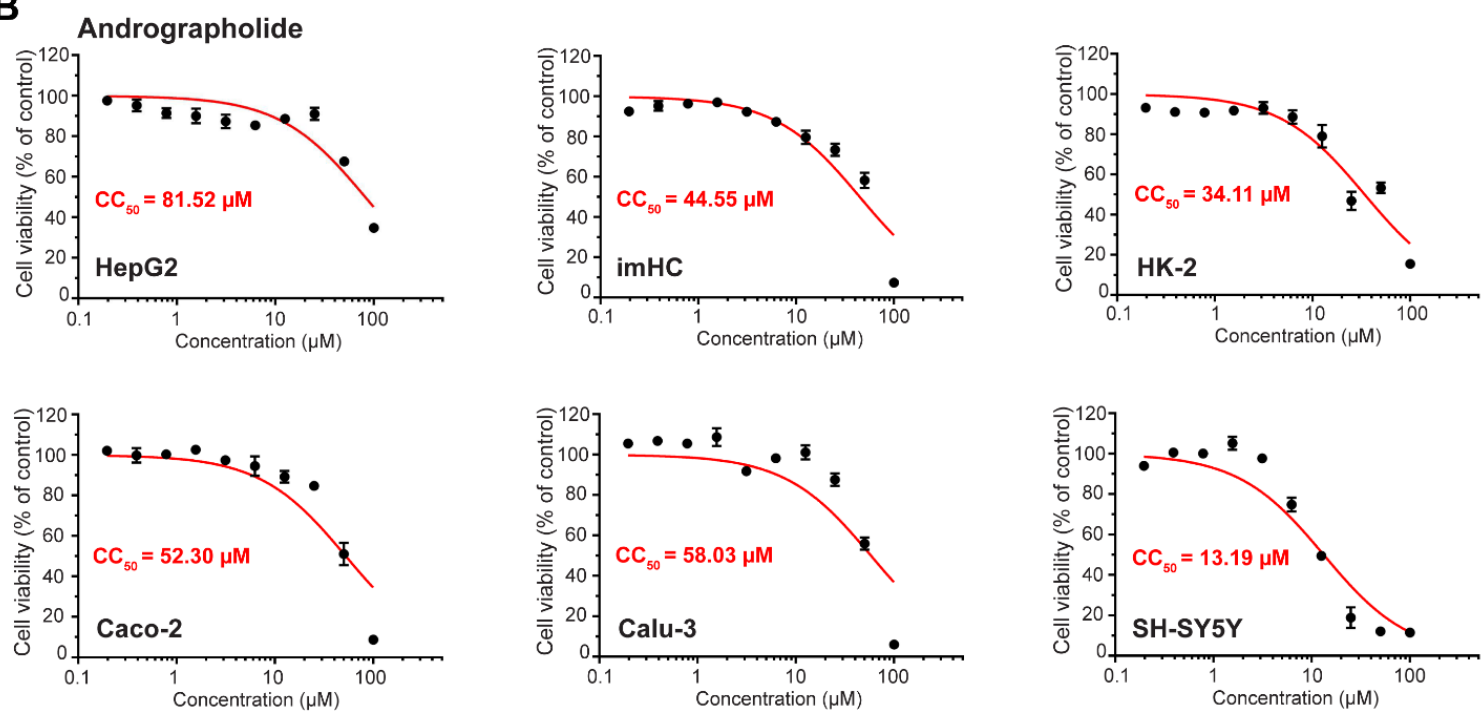

Figure 4. Cytotoxicity profiles of $A$. paniculata extract and Andrographolide over six cell lines representing human major organ. After $48 \mathrm{~h}$ treatment of (A) A. paniculata extract and (B) andrographolide in various cell lines representing liver (HepG2, imHC), kidney (HK-2), intestine (Caco-2), lung (Calu-3), and brain (SH-SY5Y), MTT assay was applied to evaluate the cytotoxicity effect. All experiments were performed in three biological replicates. 


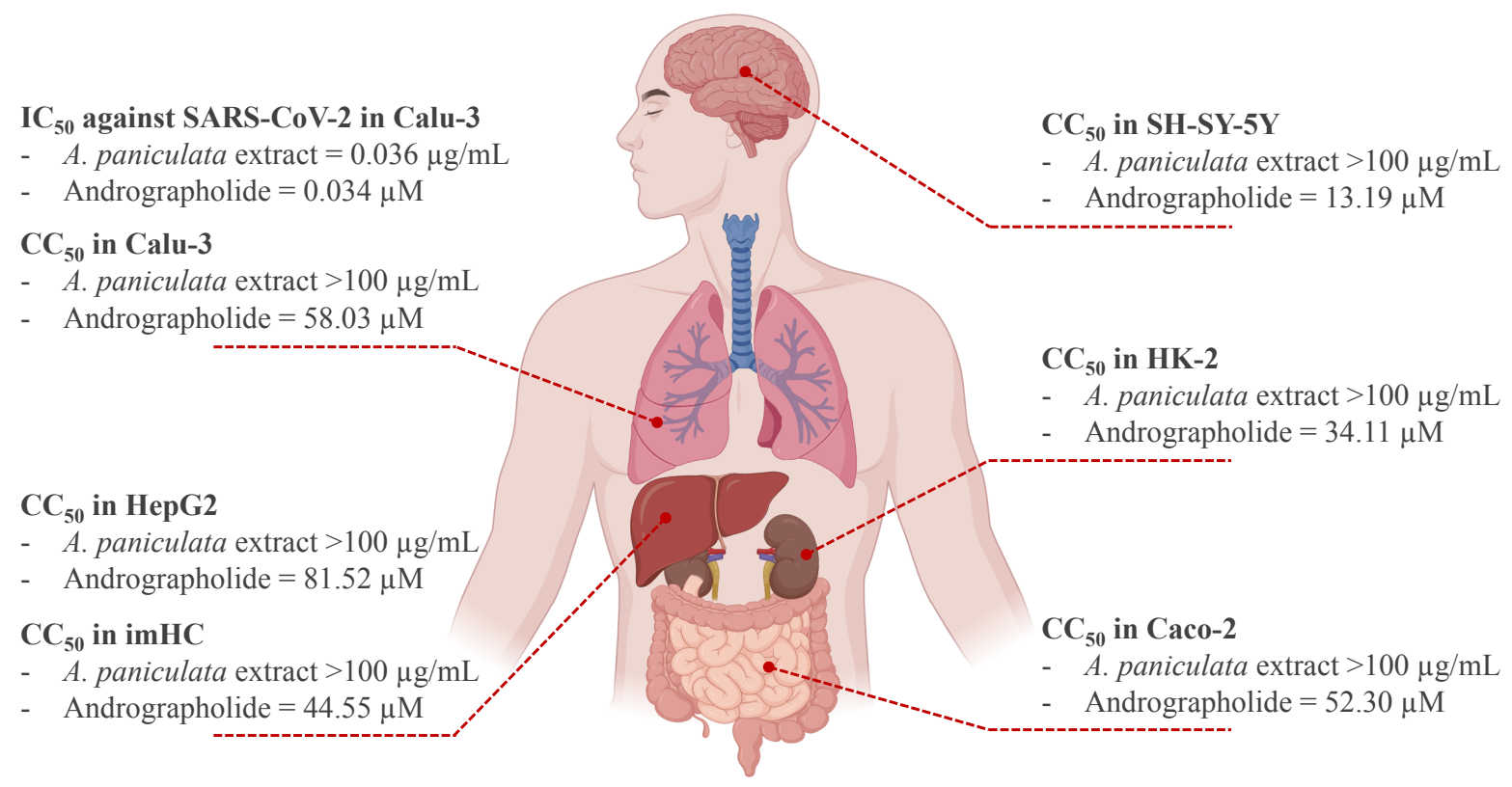

Figure 5. A schematic diagram summarized the $\mathrm{IC}_{50}$ and $\mathrm{CC}_{50}$ of $A$. paniculata extract and andrographolide across cell line representatives of human major organs.

This finding pointed out that further development of $A$. paniculata extract and andrographolide in preclinical models of COVID-19 should pay attention to the neurologic side effects as well as the amount of andrographolide that pass through the blood brain barrier. In this regard, the BOILED-egg plot using SwissADME program was performed for in silico prediction of the probability of compounds being gastrointestinal absorption and barrier penetration. ${ }^{34,35}$ Based on this prediction, andrographolide is a gastrointestinal absorbable compound without an ability to pass through the blood-brain barrier (Supplementary Figure 1). The SwissADME prediction also reveals that andrographolide is a P-glycoprotein (P-gp) substrate,$^{36}$ suggesting that andrographolide would be "pumped out" from central nervous system (CNS) tissues and may not pose a significant neurotoxicity if used in further studies.

\section{Potential clinical applications of $A$. paniculata extract and andrographolide}

Andrographis paniculata has classified as an essential plant for traditional medicine in various Asian countries for centuries. ${ }^{37}$ In Thailand, the Ministry of Public Health has registered this plant, so-called Fah Talai Jone, to The National List of Essential Drugs A.D. 1999 (List of Herbal Medicinal Products). ${ }^{38}$ A. paniculata extract has long been available in Thailand's markets as the herbal nutraceuticals in several recipes and brands, in which general population can access and use to treat diarrhea, fever, common cold and viral infection. It is postulated that beneficial effects of $A$. paniculata extract largely depended on its major component andrographolide, the bicyclic diterpene lactone with multi-functionalities including anticancer, antioxidant, antiinflammatory, immunomodulatory, cardiovascular protection and hepatoprotection, antimicrobial, antiprotozoal. ${ }^{37,39-42}$

Andrographolide is also well-known for its broad spectrum antiviral properties. ${ }^{24}$ Studies showed andrographolide has been effective against influenza $\mathrm{A},{ }^{43}$ hepatitis $\mathrm{C}$ virus, ${ }^{44}$ Chikungunya virus, ${ }^{40} \mathrm{HIV},{ }^{45}$ hepatitis B virus, ${ }^{46}$ Herpes simplex virus $1,{ }^{47}$ Epstein-Barr virus ${ }^{48}$ and human papillomavirus. ${ }^{49}$ This study showed that both $A$. paniculata extract and its active component 
andrographolide had potent inhibitory effect against SARS-CoV-2. This finding opens a possibility to develop A. paniculata extract and andrographolide in the context of COVID-19 treatment. In comparison to our previous study, ${ }^{30} A$. paniculata extract and andrographolide exhibited the equivalent $\mathrm{IC}_{50}$ against SARS-CoV-2 infection to remdesivir ${ }^{30}$ (Table 1). This is an additional rationale to support $A$. paniculata extract and especially andrographolide for further antiviral development.

It has been proposed that andrographolide involves at multiple steps of viral life cycle including viral entry, genetic material replication, protein synthesis and inhibit the expression or function of the mature proteins. ${ }^{24}$ Previous studies suggested andrographolide targeted nonstructural proteins of SARS-CoV-2 as the mechanism of action. Enzyme-based assay and in silico modelling prediction showed andrographolide could inhibit the main protease $\left(\mathrm{M}^{\text {pro }}\right)$ activities of SARS-CoV-2 with the $\mathrm{IC}_{50}$ of $15 \mu \mathrm{M}^{26,}{ }^{29}$ In addition, Maurya, VK, et al. ${ }^{50}$ showed that andrographolide has significant binding affinity towards spike glycoprotein of both SARS-CoV-2 and ACE2 receptor and could be develop as a prophylactic agent for limiting viral entry into the host cells. In our study, andrographolide inhibited SARS-CoV-2 at the viral replication and viral release as evidenced from the high-content imaging IFA and viral output study using plaque assay (Figure 2). This finding highlighted andrographolide as a potential monotherapy, even though the combinational regimens should be prioritized to increasing the efficacy and reducing the side effects/toxicities.

This study associated with several limitations. Although our findings support andrographolide as a promising candidate for further anti-SARS-CoV-2 development, the low bioavailability of andrographolide might pose a limitation for clinical applications. ${ }^{51,52}$ Several strategies have been developed to improve andrographolide solubility and bioavailability, i.e., forming complexes with hydroxypropyl- $\beta$-cyclodextrin (HP- $\beta-C D),{ }^{53}$ solid dispersion using a spray-drying technique, ${ }^{54}$ and loading into the nano-emulsion..$^{55}$ Also, it should be noted that this study was conducted using in vitro cellular model. The safety and efficacy of andrographolide should be further investigated in preclinical animal models and clinical studies.

In conclusion, this study demonstrated anti-SARS-CoV-2 activity of $A$. paniculata and andrographolide using Calu-3-based anti-SARS-CoV-2 assay. Potent anti-SAR-CoV-2 activities, together with the favorable cytotoxicity profiles, support further development of $\mathrm{A}$. paniculata extract and especially andrographolide as a monotherapy or in combination with other effective drugs against SARS-CoV-2 infection. 


\section{ACKNOWLEDGMENTS}

We thank Department of Disease Control, Ministry of Public Health Thailand for providing the clinical specimens for viral isolation. This study was supported by the Ramathibodi Research Cluster Grant (CF63010), Faculty of Medicine Ramathibodi Hospital, and Faculty of Science, Mahidol University, Thailand. KS was financially supported by Office of National Higher Education Science Research and Innovation Policy Council through Program Management Unit for Competitiveness (C10F630093). SoC was financially supported by the Faculty Staff Development Program of Faculty of Medicine Ramathibodi Hospital and the Office of National Higher Education Science Research and Innovation Policy Council of Thailand (NXPO; PMU-B).

SH was supported by the Ramathibodi Foundation. SB was supported by the Thailand Center of Excellence for Life Sciences (TCELS) Grant (TC-A15/63). AT was supported by the Chaophaya Abhaibhubejhr Hospital Foundation.

\section{CONFLICTS OF INTEREST}

All authors declare no conflicts of interest.

\section{AUTHOR CONTRIBUTIONS}

SB, AT, SH initiate the conception. AS, PKh, SoC, SB, AT, SH developed the design. KS, YP, PT, PKa, SM, SiC performed experiments. All authors analyzed and interpreted the data. KS, AS, YP, PK, SiC, SoC prepared figures and tables. KS and AS wrote the first draft of the manuscript. YP, PT, PKa, SM, SiC, PW, SP, PKh, SoC, SB, AT, SH revised the manuscript. SB and AT finalized the manuscript. SH contributed to the overall research strategy. All authors read and approved the final version of the manuscript.

\section{REFERENCES}

1. Huang, J. T.; Ran, R. X.; Lv, Z. H.; Feng, L. N.; Ran, C. Y.; Tong, Y. Q.; Li, D.; Su, H. W.; Zhu, C. L.; Qiu, S. L.; Yang, J.; Xiao, M. Y.; Liu, M. J.; Yang, Y. T.; Liu, S. M.; Li, Y., Chronological Changes of Viral Shedding in Adult Inpatients with COVID-19 in Wuhan, China. Clin Infect Dis 2020.

2. Chan, J. F. W.; Lau, S. K. P.; To, K. K. W.; Cheng, V. C. C.; Woo, P. C. Y.; Yuen, K.-Y., Middle East Respiratory Syndrome Coronavirus: Another Zoonotic Betacoronavirus Causing SARS-Like Disease. 2015, 28, (2), 465-522.

3. Cheng, V. C.; Lau, S. K.; Woo, P. C.; Yuen, K. Y., Severe acute respiratory syndrome coronavirus as an agent of emerging and reemerging infection. Clin Microbiol Rev 2007, 20, (4), 660-94.

4. Zhu, N.; Zhang, D.; Wang, W.; Li, X.; Yang, B.; Song, J.; Zhao, X.; Huang, B.; Shi, W.; Lu, R.; Niu, P.; Zhan, F.; Ma, X.; Wang, D.; Xu, W.; Wu, G.; Gao, G. F.; Tan, W.; China Novel Coronavirus, I.; Research, T., A Novel Coronavirus from Patients with Pneumonia in China, 2019. N Engl J Med 2020, 382, (8), 727-733. 
5. Gorbalenya, A. E.; Baker, S. C.; Baric, R. S.; de Groot, R. J.; Drosten, C.; Gulyaeva, A. A.; Haagmans, B. L.; Lauber, C.; Leontovich, A. M.; Neuman, B. W.; Penzar, D.; Perlman, S.; Poon, L. L. M.; Samborskiy, D. V.; Sidorov, I. A.; Sola, I.; Ziebuhr, J.; Coronaviridae Study Group of the International Committee on Taxonomy of, V., The species Severe acute respiratory syndrome-related coronavirus: classifying 2019-nCoV and naming it SARS-CoV2. Nature Microbiology 2020, 5, (4), 536-544.

6. Chan, J. F.-W.; Yuan, S.; Kok, K.-H.; To, K. K.-W.; Chu, H.; Yang, J.; Xing, F.; Liu, J.; Yip, C. C.-Y.; Poon, R. W.-S.; Tsoi, H.-W.; Lo, S. K.-F.; Chan, K.-H.; Poon, V. K.-M.; Chan, W.M.; Ip, J. D.; Cai, J.-P.; Cheng, V. C.-C.; Chen, H.; Hui, C. K.-M.; Yuen, K.-Y., A familial cluster of pneumonia associated with the 2019 novel coronavirus indicating person-to-person transmission: a study of a family cluster. The Lancet 2020, 395, (10223), 514-523.

7. Jiehao, C.; Jin, X.; Daojiong, L.; Zhi, Y.; Lei, X.; Zhenghai, Q.; Yuehua, Z.; Hua, Z.; Ran, J.; Pengcheng, L.; Xiangshi, W.; Yanling, G.; Aimei, X.; He, T.; Hailing, C.; Chuning, W.; Jingjing, L.; Jianshe, W.; Mei, Z., A Case Series of Children With 2019 Novel Coronavirus Infection: Clinical and Epidemiological Features. Clinical Infectious Diseases 2020, 71, (6), 1547-1551.

8. Verity, R.; Okell, L. C.; Dorigatti, I.; Winskill, P.; Whittaker, C.; Imai, N.; CuomoDannenburg, G.; Thompson, H.; Walker, P. G. T.; Fu, H.; Dighe, A.; Griffin, J. T.; Baguelin, M.; Bhatia, S.; Boonyasiri, A.; Cori, A.; Cucunuba, Z.; FitzJohn, R.; Gaythorpe, K.; Green, W.; Hamlet, A.; Hinsley, W.; Laydon, D.; Nedjati-Gilani, G.; Riley, S.; van Elsland, S.; Volz, E.; Wang, H.; Wang, Y.; Xi, X.; Donnelly, C. A.; Ghani, A. C.; Ferguson, N. M., Estimates of the severity of coronavirus disease 2019: a model-based analysis. Lancet Infect Dis 2020, 20, (6), 669-677.

9. Guan, W. J.; Ni, Z. Y.; Hu, Y.; Liang, W. H.; Ou, C. Q.; He, J. X.; Liu, L.; Shan, H.; Lei, C. L.; Hui, D. S. C.; Du, B.; Li, L. J.; Zeng, G.; Yuen, K. Y.; Chen, R. C.; Tang, C. L.; Wang, T.; Chen, P. Y.; Xiang, J.; Li, S. Y.; Wang, J. L.; Liang, Z. J.; Peng, Y. X.; Wei, L.; Liu, Y.; Hu, Y. H.; Peng, P.; Wang, J. M.; Liu, J. Y.; Chen, Z.; Li, G.; Zheng, Z. J.; Qiu, S. Q.; Luo, J.; Ye, C. J.; Zhu, S. Y.; Zhong, N. S.; China Medical Treatment Expert Group for, C., Clinical Characteristics of Coronavirus Disease 2019 in China. N Engl J Med 2020, 382, (18), 17081720 .

10. Huang, C.; Wang, Y.; Li, X.; Ren, L.; Zhao, J.; Hu, Y.; Zhang, L.; Fan, G.; Xu, J.; Gu, X.; Cheng, Z.; Yu, T.; Xia, J.; Wei, Y.; Wu, W.; Xie, X.; Yin, W.; Li, H.; Liu, M.; Xiao, Y.; Gao, H.; Guo, L.; Xie, J.; Wang, G.; Jiang, R.; Gao, Z.; Jin, Q.; Wang, J.; Cao, B., Clinical features of patients infected with 2019 novel coronavirus in Wuhan, China. Lancet 2020, 395, (10223), 497-506.

11. Jeon, S.; Ko, M.; Lee, J.; Choi, I.; Byun, S. Y.; Park, S.; Shum, D.; Kim, S., Identification of Antiviral Drug Candidates against SARS-CoV-2 from FDA-Approved Drugs. Antimicrob Agents Chemother 2020, 64, (7), e00819-20.

12. Riva, L.; Yuan, S.; Yin, X.; Martin-Sancho, L.; Matsunaga, N.; Pache, L.; BurgstallerMuehlbacher, S.; De Jesus, P. D.; Teriete, P.; Hull, M. V.; Chang, M. W.; Chan, J. F.; Cao, J.; Poon, V. K.; Herbert, K. M.; Cheng, K.; Nguyen, T. H.; Rubanov, A.; Pu, Y.; Nguyen, C.; Choi, A.; Rathnasinghe, R.; Schotsaert, M.; Miorin, L.; Dejosez, M.; Zwaka, T. P.; Sit, K. Y.; Martinez-Sobrido, L.; Liu, W. C.; White, K. M.; Chapman, M. E.; Lendy, E. K.; Glynne, R. 
J.; Albrecht, R.; Ruppin, E.; Mesecar, A. D.; Johnson, J. R.; Benner, C.; Sun, R.; Schultz, P. G.; Su, A. I.; Garcia-Sastre, A.; Chatterjee, A. K.; Yuen, K. Y.; Chanda, S. K., Discovery of SARS-CoV-2 antiviral drugs through large-scale compound repurposing. Nature 2020, 586, (7827), 113-119.

13. Shyr, Z. A.; Gorshkov, K.; Chen, C. Z.; Zheng, W., Drug Discovery Strategies for SARSCoV-2. J Pharmacol Exp Ther 2020, 375, (1), 127-138.

14. Choy, K. T.; Wong, A. Y.; Kaewpreedee, P.; Sia, S. F.; Chen, D.; Hui, K. P. Y.; Chu, D. K. W.; Chan, M. C. W.; Cheung, P. P.; Huang, X.; Peiris, M.; Yen, H. L., Remdesivir, lopinavir, emetine, and homoharringtonine inhibit SARS-CoV-2 replication in vitro. Antiviral research 2020, 178, 104786.

15. Spinner, C. D.; Gottlieb, R. L.; Criner, G. J.; Arribas Lopez, J. R.; Cattelan, A. M.; Soriano Viladomiu, A.; Ogbuagu, O.; Malhotra, P.; Mullane, K. M.; Castagna, A.; Chai, L. Y. A.; Roestenberg, M.; Tsang, O. T. Y.; Bernasconi, E.; Le Turnier, P.; Chang, S. C.; SenGupta, D.; Hyland, R. H.; Osinusi, A. O.; Cao, H.; Blair, C.; Wang, H.; Gaggar, A.; Brainard, D. M.; McPhail, M. J.; Bhagani, S.; Ahn, M. Y.; Sanyal, A. J.; Huhn, G.; Marty, F. M.; Investigators, G.-U.-. Effect of Remdesivir vs Standard Care on Clinical Status at 11 Days in Patients With Moderate COVID-19: A Randomized Clinical Trial. JAMA 2020, 324, (11), 1048-1057.

16. Beigel, J. H.; Tomashek, K. M.; Dodd, L. E.; Mehta, A. K.; Zingman, B. S.; Kalil, A. C.; Hohmann, E.; Chu, H. Y.; Luetkemeyer, A.; Kline, S.; Lopez de Castilla, D.; Finberg, R. W.; Dierberg, K.; Tapson, V.; Hsieh, L.; Patterson, T. F.; Paredes, R.; Sweeney, D. A.; Short, W. R.; Touloumi, G.; Lye, D. C.; Ohmagari, N.; Oh, M. D.; Ruiz-Palacios, G. M.; Benfield, T.; Fatkenheuer, G.; Kortepeter, M. G.; Atmar, R. L.; Creech, C. B.; Lundgren, J.; Babiker, A. G.; Pett, S.; Neaton, J. D.; Burgess, T. H.; Bonnett, T.; Green, M.; Makowski, M.; Osinusi, A.; Nayak, S.; Lane, H. C.; Members, A.-S. G., Remdesivir for the Treatment of Covid-19 Final Report. N Engl J Med 2020, 383, (19), 1813-1826.

17. Dyer, O., Covid-19: Remdesivir has little or no impact on survival, WHO trial shows. $B M J$ 2020, 371, m4057.

18. Newman, D. J.; Cragg, G. M., Natural Products as Sources of New Drugs from 1981 to 2014. Journal of Natural Products 2016, 79, (3), 629-661.

19. Siddiqui, A. J.; Danciu, C.; Ashraf, S. A.; Moin, A.; Singh, R.; Alreshidi, M.; Patel, M.; Jahan, S.; Kumar, S.; Alkhinjar, M. I. M.; Badraoui, R.; Snoussi, M.; Adnan, M., Plants-Derived Biomolecules as Potent Antiviral Phytomedicines: New Insights on Ethnobotanical Evidences against Coronaviruses. Plants 2020, 9, (9), 1244.

20. Khare, P.; Sahu, U.; Pandey, S. C.; Samant, M., Current approaches for target-specific drug discovery using natural compounds against SARS-CoV-2 infection. Virus Res 2020, 290, 198169.

21. Pholphana, N.; Rangkadilok, N.; Saehun, J.; Ritruechai, S.; Satayavivad, J., Changes in the contents of four active diterpenoids at different growth stages in Andrographis paniculata (Burm.f.) Nees (Chuanxinlian). Chin Med 2013, 8, (1), 2.

22. Hossain, M. S.; Urbi, Z.; Sule, A.; Hafizur Rahman, K. M., Andrographis paniculata (Burm. f.) Wall. ex Nees: a review of ethnobotany, phytochemistry, and pharmacology. ScientificWorldJournal 2014, 2014, 274905. 
23. Koteswara Rao, Y.; Vimalamma, G.; Rao, C. V.; Tzeng, Y. M., Flavonoids and andrographolides from Andrographis paniculata. Phytochemistry 2004, 65, (16), 2317-21.

24. Gupta, S.; Mishra, K. P.; Ganju, L., Broad-spectrum antiviral properties of andrographolide. Arch Virol 2017, 162, (3), 611-623.

25. Alagu Lakshmi, S.; Shafreen, R. M. B.; Priya, A.; Shunmugiah, K. P., Ethnomedicines of Indian origin for combating COVID-19 infection by hampering the viral replication: using structure-based drug discovery approach. J Biomol Struct Dyn 2020, 1-16.

26. Enmozhi, S. K.; Raja, K.; Sebastine, I.; Joseph, J., Andrographolide as a potential inhibitor of SARS-CoV-2 main protease: an in silico approach. J Biomol Struct Dyn 2020, 1-7.

27. Linda Laksmiani, N. P.; Febryana Larasanty, L. P.; Gde Jaya Santika, A. A.; Andika Prayoga, P. A.; Intan Kharisma Dewi, A. A.; Ayu Kristiara Dewi, N. P., Active Compounds Activity from the Medicinal Plants Against SARS-CoV-2 using in Silico Assay. Biomedical and Pharmacology Journal 2020, 13, (02), 873-881.

28. Murugan, N. A.; Pandian, C. J.; Jeyakanthan, J., Computational investigation on Andrographis paniculata phytochemicals to evaluate their potency against SARS-CoV-2 in comparison to known antiviral compounds in drug trials. J Biomol Struct Dyn 2020, 1-12.

29. Shi, T. H.; Huang, Y. L.; Chen, C. C.; Pi, W. C.; Hsu, Y. L.; Lo, L. C.; Chen, W. Y.; Fu, S. L.; Lin, C. H., Andrographolide and its fluorescent derivative inhibit the main proteases of 2019-nCoV and SARS-CoV through covalent linkage. Biochem Biophys Res Commun 2020.

30. Kanjanasirirat, P.; Suksatu, A.; Manopwisedjaroen, S.; Munyoo, B.; Tuchinda, P.; Jearawuttanakul, K.; Seemakhan, S.; Charoensutthivarakul, S.; Wongtrakoongate, P.; Rangkasenee, N.; Pitiporn, S.; Waranuch, N.; Chabang, N.; Khemawoot, P.; Sa-ngiamsuntorn, K.; Pewkliang, Y.; Thongsri, P.; Chutipongtanate, S.; Hongeng, S.; Borwornpinyo, S.; Thitithanyanont, A., High-content screening of Thai medicinal plants reveals Boesenbergia rotunda extract and its component Panduratin A as anti-SARS-CoV-2 agents. Scientific Reports 2020, 10, (1), 19963.

31. Hoffmann, M.; Mosbauer, K.; Hofmann-Winkler, H.; Kaul, A.; Kleine-Weber, H.; Kruger, N.; Gassen, N. C.; Muller, M. A.; Drosten, C.; Pohlmann, S., Chloroquine does not inhibit infection of human lung cells with SARS-CoV-2. Nature 2020, 585, (7826), 588-590.

32. Jeon, S.; Ko, M.; Lee, J.; Choi, I.; Byun, S. Y.; Park, S.; Shum, D.; Kim, S., Identification of Antiviral Drug Candidates against SARS-CoV-2 from FDA-Approved Drugs. Antimicrob Agents Chemother 2020, 64, (7).

33. Pindiprolu, S.; Pindiprolu, S. H., Plausible mechanisms of Niclosamide as an antiviral agent against COVID-19. Med Hypotheses 2020, 140, 109765.

34. Daina, A.; Michielin, O.; Zoete, V., SwissADME: a free web tool to evaluate pharmacokinetics, drug-likeness and medicinal chemistry friendliness of small molecules. Scientific Reports 2017, 7, (1), 42717.

35. Daina, A.; Zoete, V., A BOILED-Egg To Predict Gastrointestinal Absorption and Brain Penetration of Small Molecules. ChemMedChem 2016, 11, (11), 1117-1121. 
36. Szakacs, G.; Varadi, A.; Ozvegy-Laczka, C.; Sarkadi, B., The role of ABC transporters in drug absorption, distribution, metabolism, excretion and toxicity (ADME-Tox). Drug Discov Today 2008, 13, (9-10), 379-93.

37. Dai, Y.; Chen, S.-R.; Chai, L.; Zhao, J.; Wang, Y.; Wang, Y., Overview of pharmacological activities of Andrographis paniculata and its major compound andrographolide. Critical Reviews in Food Science and Nutrition 2019, 59, (sup1), S17-S29.

38. Jarukamjorn, K.; Nemoto, N., Pharmacological Aspects of $<\mathbf{i}>$ Andrographis paniculata $</ \mathbf{i}>$ on Health and Its Major Diterpenoid Constituent Andrographolide. Journal of Health Science 2008, 54, (4), 370-381.

39. Mussard, E.; Cesaro, A.; Lespessailles, E.; Legrain, B.; Berteina-Raboin, S.; Toumi, H., Andrographolide, A Natural Antioxidant: An Update. Antioxidants 2019, 8, (12), 571.

40. Wintachai, P.; Kaur, P.; Lee, R. C.; Ramphan, S.; Kuadkitkan, A.; Wikan, N.; Ubol, S.; Roytrakul, S.; Chu, J. J.; Smith, D. R., Activity of andrographolide against chikungunya virus infection. Sci Rep 2015, 5, (1), 14179.

41. Akbar, S., Andrographis paniculata: a review of pharmacological activities and clinical effects. Altern Med Rev 2011, 16, (1), 66-77.

42. Mishra, K.; Dash, A. P.; Dey, N., Andrographolide: A Novel Antimalarial Diterpene Lactone Compound from $<\mathrm{i}>$ Andrographis paniculata $</ \mathrm{i}>$ and Its Interaction with Curcumin and Artesunate. Journal of Tropical Medicine 2011, 2011, 579518.

43. Chen, J. X.; Xue, H. J.; Ye, W. C.; Fang, B. H.; Liu, Y. H.; Yuan, S. H.; Yu, P.; Wang, Y. Q., Activity of andrographolide and its derivatives against influenza virus in vivo and in vitro. Biol Pharm Bull 2009, 32, (8), 1385-91.

44. Lee, J. C.; Tseng, C. K.; Young, K. C.; Sun, H. Y.; Wang, S. W.; Chen, W. C.; Lin, C. K.; $\mathrm{Wu}, \mathrm{Y}$. H., Andrographolide exerts anti-hepatitis $\mathrm{C}$ virus activity by up-regulating haeme oxygenase-1 via the p38 MAPK/Nrf2 pathway in human hepatoma cells. British journal of pharmacology 2014, 171, (1), 237-52.

45. Reddy, V. L.; Reddy, S. M.; Ravikanth, V.; Krishnaiah, P.; Goud, T. V.; Rao, T. P.; Ram, T. S.; Gonnade, R. G.; Bhadbhade, M.; Venkateswarlu, Y., A new bis-andrographolide ether from Andrographis paniculata nees and evaluation of anti-HIV activity. Nat Prod Res 2005, 19, (3), 223-30.

46. Chen, H.; Ma, Y. B.; Huang, X. Y.; Geng, C. A.; Zhao, Y.; Wang, L. J.; Guo, R. H.; Liang, W. J.; Zhang, X. M.; Chen, J. J., Synthesis, structure-activity relationships and biological evaluation of dehydroandrographolide and andrographolide derivatives as novel anti-hepatitis B virus agents. Bioorg Med Chem Lett 2014, 24, (10), 2353-9.

47. Seubsasana, S.; Pientong, C.; Ekalaksananan, T.; Thongchai, S.; Aromdee, C., A potential andrographolide analogue against the replication of herpes simplex virus type 1 in vero cells. Med Chem 2011, 7, (3), 237-44.

48. Lin, T. P.; Chen, S. Y.; Duh, P. D.; Chang, L. K.; Liu, Y. N., Inhibition of the epstein-barr virus lytic cycle by andrographolide. Biol Pharm Bull 2008, 31, (11), 2018-23.

49. Ekalaksananan, T.; Sookmai, W.; Fangkham, S.; Pientong, C.; Aromdee, C.; Seubsasana, S.; Kongyingyoes, B., Activity of Andrographolide and Its Derivatives on HPV16 Pseudovirus 
Infection and Viral Oncogene Expression in Cervical Carcinoma Cells. Nutr Cancer 2015, 67, (4), 687-96.

50. Maurya, V. K.; Kumar, S.; Prasad, A. K.; Bhatt, M. L. B.; Saxena, S. K., Structure-based drug designing for potential antiviral activity of selected natural products from Ayurveda against SARS-CoV-2 spike glycoprotein and its cellular receptor. VirusDisease 2020, 31, (2), 179193.

51. Asprea, M.; Tatini, F.; Piazzini, V.; Rossi, F.; Bergonzi, M. C.; Bilia, A. R., Stable, Monodisperse, and Highly Cell-Permeating Nanocochleates from Natural Soy Lecithin Liposomes. Pharmaceutics 2019, 11, (1), 34.

52. Chen, H. W.; Huang, C. S.; Li, C. C.; Lin, A. H.; Huang, Y. J.; Wang, T. S.; Yao, H. T.; Lii, C. K., Bioavailability of andrographolide and protection against carbon tetrachloride-induced oxidative damage in rats. Toxicology and applied pharmacology 2014, 280, (1), 1-9.

53. Ren, K.; Zhang, Z.; Li, Y.; Liu, J.; Zhao, D.; Zhao, Y.; Gong, T., Physicochemical characteristics and oral bioavailability of andrographolide complexed with hydroxypropyl\&\#946;-cyclodextrin. Die Pharmazie - An International Journal of Pharmaceutical Sciences 2009, 64, (8), 515-520.

54. Bothiraja, C.; Shinde, M. B.; Rajalakshmi, S.; Pawar, A. P., Evaluation of molecular pharmaceutical and in-vivo properties of spray-dried isolated andrographolide-PVP. Journal of Pharmacy and Pharmacology 2009, 61, (11), 1465-1472.

55. Yen, C. C.; Chen, Y. C.; Wu, M. T.; Wang, C. C.; Wu, Y. T., Nanoemulsion as a strategy for improving the oral bioavailability and anti-inflammatory activity of andrographolide. Int $J$ Nanomedicine 2018, 13, 669-680.

56. Sa-ngiamsuntorn, K.; Wongkajornsilp, A.; Kasetsinsombat, K.; Duangsa-ard, S.; Nuntakarn, L.; Borwornpinyo, S.; Akarasereenont, P.; Limsrichamrern, S.; Hongeng, S., Upregulation of CYP 450s expression of immortalized hepatocyte-like cells derived from mesenchymal stem cells by enzyme inducers. BMC Biotechnol 2011, 11, (1), 89.

57. Pewkliang, Y.; Rungin, S.; Lerdpanyangam, K.; Duangmanee, A.; Kanjanasirirat, P.; Suthivanich, P.; Sa-Ngiamsuntorn, K.; Borwornpinyo, S.; Sattabongkot, J.; Patrapuvich, R.; Hongeng, S., A novel immortalized hepatocyte-like cell line (imHC) supports in vitro liver stage development of the human malarial parasite Plasmodium vivax. Malar J 2018, 17, (1), 50.

58. Sa-Ngiamsuntorn, K.; Thongsri, P.; Pewkliang, Y.; Wongkajornsilp, A.; Kongsomboonchoke, P.; Suthivanich, P.; Borwornpinyo, S.; Hongeng, S., An Immortalized Hepatocyte-like Cell Line (imHC) Accommodated Complete Viral Lifecycle, Viral Persistence Form, cccDNA and Eventual Spreading of a Clinically-Isolated HBV. Viruses 2019, 11, (10), 952.

59. Reed, L. J.; Muench, H., A simple method of estimating fifty per cent endpoints. American Journal of Epidemiology 1938, 27, (3), 493-497.

60. Najib, Y.; Wan-Azemin, A.; Dharmaraj, S.; Suryati, K., Phytochemical Screening and Prophylactic Antibacterial Effects of Andrographis Paniculata Extracts from Kemaman, Malaysia. Journal of Natural Sciences Research 2015, 5, 67-72. 
61. Sani, Y. N.; Danladi, S.; Wan-Azemin, A.; US, M. R.; Mohd, K. S.; Dharmaraj, S., Effects of extracting solvents on total phenolic content, total flavonoid content and anti-oxidant activity of Andrographis paniculata from Kemaman, Malaysia. Research Journal of Pharmaceutical, Biological and Chemical Sciences 2015, 6, 1397-1404. 